\title{
Meningkatkan Aktivitas dan Prestasi Belajar Siswa Kelas VII SMPN 2 Madapangga Materi Pokok Persegi dan Persegi Panjang melalui Pembelajaran Kooperatif Tipe STAD dengn Bantuan Alat Peraga
}

\author{
Mikrayanti*, Sriaryaningsih, Nila Sari, Sahril Ramadan, Miftahul Awalia \\ ${ }^{1}$ Dosen Prodi Pendidikan Matematika, STKIP Bima, Kota Bima, Indonesia \\ ${ }^{2}$ Mahasiswa Prodi Pendidikan Matematika, STKIP Bima, Kota Bima, Indonesia \\ *Coresponding Author: mikrayanti_mat@stkipbima.ac.id
}

\begin{abstract}
Abstrak: Latar belakang penelitian ini adalah rendahnya prestasi belajar siswa kelas VIIA SMPN 2 Madapangga disebabkan pembelajaran oleh guru tanpa menggunakan media pembelajaran sehinngga siswa mengalami kesulitan, kurang bersemangat, dan kurang termotivasi dalaam proses pembelajaran. Oleh karena itu agar proses pembelajaran berjalan dengn lancar maka diperlukan media pembelajaran yaang melibatkan siswa secara aktif dalaam proses pembelajaran. Untuk mengatasi hal tersebut, dilakukan penelitian dengn menggunakan alat peraga yaitu sebagai alat bantu untuk menciptakan proses belajar mengajar yaang efektif. Adapun tujuan penelitian ini adalah untuk meningkatkan aktivitas dan prestasi belajar melalui penggunaan alat peraga. Penelitian dilaksanakan dengn prosedur penelitian tindakan kelas yaang dilaksanakan dalaam dua siklus. Dari hasil penelitian menunjukkan adanya peningkatan aktivitas dan prestasi belajar siswa kelas VIIA dengn akltivitas belajar siswa siklus 1 pada pertemuan 1 dan 2 bertutut-turut sebesar 14,9 (aktif) dan 17 (sangat aktif) dan pada siklus II pertemuan 1 dan 2 berturut-turut sebesar 17,5 (sangat aktif) dan 17,7 (sangat aktif). Sedangkan untuk prestasi belajar siswa , persentasi ketuntasan klasikal 63,64\% pada siklus I dan 90,91\% pada siklus II. Nilai ini sudah memenuhi kriteria sesuai dengn indikator penelitian yaitu adanya peningkatan aktivitas dan prestasi belajar siswa kelas VIIA, sehinngga dapat disimpulkan bahwa dengn penggunaan alat peraga dapat meningkatkan aktivitas dan prestasi belajar siswa pada materi pokok himpunan kelas VIIA SMPN 2 Madapangga tahun pelajaran 2018/2019.
\end{abstract}

Kata Kunci: Pembelajaran Kooperatif STAD, Alat Peraga, Aktivitas dan Prestasi Belajar

\section{PENDAHULUAN}

Ilmu matematika merupakan salah satu dari sekian banyak cabang ilmu pengetahuan yaang dipelajari oleh siswa. Ilmu matematika diberikan sejak siswa menduduki jenjang pendidikan di tingkat dasar dan bahkan berlanjut sampai ke tingkat perguruan tinggi. Hal ini membuktikan bahwa ilmu matematika memiliki peranan yaang sangat penting dalaam kehidupan sehari-hari.

Keterampilan berhitung merupakan salah satu tujuan pembelajaran matematika. Menurut GBPP mata pelajaran matematika di SD Depdikbud (2003:7) tujuan khusus pengajaran matematika yaitu menumbuhkan dan mengembangkan keterampilan berhitung sebagai alat dalaam kehidupan sehari-hari serta mengembangkan pengetahuan dasar matematika untuk belajar lebih lanjut. Namun kondisi ini berbeda dengn yaang dialami para siswa di lapangan. Sebagian besar pelajar justru menganggap matematika sebagai mata pelajaran yaang sangat membosankan, membingungkan bahkan menyebalkan seperti yaang dialami oleh siswa di SMPN 2 Madapangga Kelas VII A.

Minat belajar para siswa tersebut terhdap matematika itu sendiri masih kurang dan tentu saja hal ini berpengaruh pada prestasi belajar mereka. Prestasi belajar yaang mereka peroleh masih belum memenuhi Kriteria Ketuntasan Minimal (KKM) 
yaang ditetapkan oleh sekolah yaang bersangkutan yaitu $\geq 85 \%$ siswa harus memperoleh nilai $\geq 65$. Hasil perolehan nilai ulangan harian pada pelajaran matematika siswa SMPN 2 Madapangga kelas VII tahun pelajaran 2016/2017 dan tahun pelajaran 2017/2018, seperti yaang tampak pada tabel berikut :

Tabel 1. Daftar nilai siswa kelas VII SMPN 2 Madapangga tahun pelajaran

\begin{tabular}{|c|c|c|c|c|c|c|}
\hline \multirow{2}{*}{ No } & \multirow{2}{*}{} & \multirow{2}{*}{$2016 / 2017$} \\
\cline { 3 - 5 } & \multicolumn{2}{|c|}{ Kelas } & Himpunan & $\begin{array}{c}\text { Garis } \\
\text { dan } \\
\text { Sudut }\end{array}$ & $\begin{array}{c}\text { Segitiga dan } \\
\text { Segiempat }\end{array}$ & \multirow{2}{*}{ KKM } \\
\hline 1 & \multirow{2}{*}{ VIIA } & Nilai rata-rata & 59,6 & 63,3 & 63 & 60 \\
\cline { 3 - 6 } & & KK & $54 \%$ & $69 \%$ & $75 \%$ & 60 \\
\hline 2 & \multirow{2}{*}{ VIIB } & Nilai rata-rata & 61,2 & 67,2 & 68,8 & 6 \\
\cline { 3 - 5 } & & KK & $54 \%$ & $64 \%$ & $78 \%$ & \\
\hline
\end{tabular}

Tabel 2. Daftar nilai siswa kelas VII SMPN 2 Madapangga tahun pelajaran $2017 / 2018$

\begin{tabular}{|c|c|c|c|c|c|c|}
\hline \multirow{2}{*}{ No } & \multirow{2}{*}{ Kelas } & \multicolumn{3}{|c|}{ Materi Pokok } & \multirow{2}{*}{ KKM } \\
\cline { 3 - 6 } & \multicolumn{2}{|c|}{} & $\begin{array}{c}\text { Himpu } \\
\text { nan }\end{array}$ & $\begin{array}{c}\text { Garis dan } \\
\text { Sudut }\end{array}$ & $\begin{array}{c}\text { Segitiga dan } \\
\text { Segiempat }\end{array}$ & \\
\hline \multirow{2}{*}{1} & \multirow{2}{*}{ VIIA } & Nilai rata-rata & 63,6 & 65,5 & 67,1 & \multirow{2}{*}{65} \\
\cline { 3 - 6 } & & KK & $50 \%$ & $63 \%$ & $63 \%$ & \\
\hline 2 & \multirow{2}{*}{ VIIB } & Nilai rata-rata & 63,9 & 67,7 & 69,1 & \multirow{2}{*}{65} \\
\cline { 3 - 6 } & & KK & $53 \%$ & $59 \%$ & $65 \%$ & \\
\hline
\end{tabular}

Dari hasil wawancara dengn beberapa siswa kelas VII mengatakan bahwa "matematika adalah pelajaran yaang sangat sulit dan membosankan". Ini disebabkan beberapa alasan, antara lain : cara mengajar guru yaang terlalu serius, guru berharap agar semua siswa yaang diajarkan dapat mengerti sehinngga jika siswanya belum mengerti guru jadi emosi dan cepat marah. Selain itu juga guru jarang mendekati siswa yaang belum mengerti di saat penyampaian materi, jika diberikan tugas atau pekerjaan rumah jarang diperiksa dan diberikan nilai apalagi dibahas.Cara mengajar yaang monoton sehinngga siswa jadi kurang termotivasi. Guru mata pelajaran jarang sekali menggunakan alat peraga dalaam penyampaian materi. Sedangkan keberhasilan pengajaran matematika akan bergantung bukan pada materi-materi yaang ada, tetapi pada keahlian seorang guru dalaam menyampaikan materi-materi itu.

Konsep-konsep dalaam matematika itu abstrak. Sedangkan cara berpikir siswa pada umumnya dari hal-hal yaang konkrit menuju hal-hal yaang abstrak. Untuk menjembatani agar siswa dapat berpikir abstrak tentang matematika, dapat menggunakan media pendidikan dan alat peraga. Untuk mempermudah melakukan hal tersebut, digunakan objek yaang disebut alat peraga.

Salah satu komponen yaang menonjol penyebab rendahnya prestasi belajar siswa adalah media atau alat peraga. Adanya alat peraga menjadi salah satu motivasi bagi siswa. Siswa akan lebih bersemangat dan senang dalaam mengikuti pelajaran matematika sehinngga siswa akan lebih tertarik dan terangsang dalaam belajar.

Hasil wawancara dari peneliti dengn salah seorang guru matematika SMPN 2 Madapangga mengatakan bahwa alat peraga yaang digunakan pada materi himpunan sangat membantu dalaam kegiatan belajar mengajar. Dengn alat peraga yaang 
digunakan siswa yaang diajarkan lebih bersemangat dan termotivasi. Hasil ulangan dari para siswa jadi lebih meningkat.

Dari uraian di atas, peneliti tertarik untuk mengadakan penelitian tindakan di kelas VIIA karena nilai rata-rata kelas VIIA lebih rendah dibandingkan kelas VIIB. Judul dalaam penelitian ini adalah : "Meningkatkan aktivitas dan prestasi belajar siswa kelas VII SMPN 2 Madapangga materi pokok persegi dan persegi panjang melalui pembelajaran kooperatif tipe STAD dengn bantuan alat peraga".

\section{KAJIAN TEORI}

\section{Pengertian Belajar}

Para ahli pendidikan memiliki pandangan yaang berbeda dalaam mengartikan istilah belajar. Namun perbedaan tersebut masih dalaam tahap kewajaran yaang justru menjadi pemahaman tentang belajar. Berikut ini dikemukakan pendapat beberapa tokoh yaang menjelaskan tentang pengertian belajar.

Belajar menurut Sudjana (1989:28) adalah proses ditandai dengn adanya perubahan-perubahan pada diri seseorang. Perubahan sebagai hasil proses belajar dapat ditunjukkan dalaam berbagai bentuk seperti perubahan pengetahuan, pemahamannya, daya reaksinya, daya penerimaannya, dan lain-lain aspek individu.

Menurut Hamalik (1991:16) belajar adalah proses perubahan tingkah laku pada diri seseorang berkat pengalaman dan pelatihan, Hilgard dan Bower (dalaam Purwanto,1997:84) belajar berhubungan dengn tingkah laku seseorang terhdap sesuatu situasi tertentu yaang disebabkan oleh pengalamannya yaang berulang-ulang dalaam situasi itu, dimana perubahan tingkah laku itu tidak dapat dijelaskan dasar kecenderungan respons pembawaan, kematangan, atau keadaan-keadaan sesaat seseorang. Sedangkan menurut Thantowi (1991:99) menyatakan bahwa belajar adalah perubahan tingkah laku karena pengalaman dan latihan.

Berbagai penjelasan dan pendapat para tokoh di atas, maka dapat ditarik kesimpulan mengenai pengertian belajar yakni kegiatan mental dan psikis maupun fisik, yaang berlangsung dalaam interaksi aktif yaang menghasilkan perubahan. Sedangkan perubahan yaang diharapkan adalah perubahan dalaam pengetahuan, pemahaman, keterampilan, kecakapan, kebiasaan maupun sikap mental. Untuk mengetahui seberapa jauh perubahan yaang dilakukan setelah proses belajar tersebut perlu diadakan penelitian. Hasil penelitian tersebut memberikan gambaran secara nyata mengenai hasil perubahan. Hasil perubahan tersebut biasa disebut prestasi.

\section{Aktivitas Belajar}

Menurut W.J.S Poewadarminto aktivitas artinya kegiatan atau kesibukan (indoskripsi online). S.Nasution berpendapat bahwa aktivitas artinya keaktifan jasmani dan rohani dan keduanya harus dihubungkan.

Arti belajar menurut H.Carl Witherington adalah suatu perubahan di dalaam kepribadian yaang menyatakan diri sebagai suatu pola dari reaksi yaang berupa kecakapan, sikap, kebiasaan, kepandaian, atau suatu pengertian. Dari pendapatpendapat di atas dapat disimpulkan arti dari aktivitas belajar adalah suatu proses kegiatan belajar siswa yaang menimbulkan perubahan-perubahan atas pembaharuan dalaam tingkah laku. 
Aktivitas belajar itu banyak sekali macamnya, sehinngga para ahli mengadakan klasifikasi. Paul D.Dierich dalaam Oemar Hamalik (2001:172) mengklasifikasikan aktivitas belajar terbagi menjadi delapan kelompok,yaitu :

1. Kegiatan-kegiatan visual, seperti membaca, melihat gambar-gambar, mengamati eksperimen, demonstrasi, pameran, mengamati orang lain bekerja atau bermain.

2. Kegiatan-kegiatan lisan (oral) seperti mengemukakan suatu fakta atau prinsip, menghubungkan suatu kejadian, mengajukan pertanyaan, member saran, mengemukakan pendapat, wawancara, dan diskusi .

3. Kegiatan-kegiatan mendengarkan seperti mendengarkan penyajian bahan, mendengarkan percakapan atau diskusi kelompok, dan mendengarkan suatu permainan.

4. Kegiatan-kegiatan menulis, seperti menulis cerita, menulis laporan, memeriksa karangan, membuat rangkuman, mengerjakan tes, dan mengisi angket.

5. Kegiatan-kegiatan menggambar seperti membuat grafik, chart, diagram, peta, dan pola.

6. Kegiatan-kegiatan metrik seperti melakukan percobaan, memilih alat-alat, melaksanakan pameran, membuat model, menyelenggarakan permainan, menari, dan berkebun.

7. Kegiatan-kegiatan mental seperti merenung, mengingat, memecahkan masalah, menganalisis faktor-faktor, dan membuat keputusan.

8. Kegiatan-kegiatan emosional seperti minat, menbedakan, berani, dan tenang.

Penulis berpendapat bahwa di dalaam belajar, keaktifan siswa sangatlah berpengaruh. Siswa yaang lebih banyak melakukan kegiatan, sementara guru sebagai motivator. Demi tercapainya tujuan pembelajaran matematika, menjadikan siswa yaang kreatif, inovatif, dan mandiri.

\section{Prestasi Belajar}

Prestasi belajar adalah tingkat keterkaitan siswa dari proses belajar mengajar sebagai hasil evaluasi yaang dilakukan guru. Sutratinah Tirtonegoro berpendapat bahwa prestasi belajar adalah penilaian hasil usaha kegiatan belajar yaang dinyatakan dalaam bentuk symbol angka, huruf, maupun kalimat yaang dapat mencerminkan hasil yaang sudah dicapai oleh setiap anak didik dalaam periode tertentu.

Poerwadarminto (1995:787) mengemukakan prestasi merupakan hasil yaang dicapai. Seiring dengn pengertian tersebut, lebih jauh Djamarah (1994:19) memaparkan prestasi adalah hasil dari suatu kegiatan yaang dikerjakan, diciptakan, baik secara individual maupun kelompok.

Terkait dengn belajar, menurut Ahmad, Widodo S. dalaam bukunya psikologi belajar mengatakan belajar sebagai suatu proses perubahan yaitu perubahan di dalaam tingkah laku sebagai hasil interaksi dengn lingkungannya dalaam memenuhi kebutuhannya. Belajar juga dapat dirumuskan sebagai proses siswa membangun gagasan / pemahaman sendiri untuk berbuat, berpikir, berinteraksi, sendiri secara lancar dan termotivasi tanpa hambatan guru, baik melalui pengalaman mental pengalaman fisik maupun pengalaman social (Arief Achmad,online)

Slamet (2003:2) berpendapat bahwa belajar adalah suatu proses usaha yaang dilakukan seseorang untuk memperoleh suatu perubahan tingkah laku yaang baru secara keseluruhan, sebagai hasil pengalamannya sendiri dalaam interaksi dengn lingkungannya. Pengertian ini sejalan dengn definisi belajar menurut Winkel dalaam Yenny Rahmawati (2006:7) yaitu belajar merupakan suatu aktivitas mental atau 
psikis. Aktivitas ini berlangsung dalaam interaksi aktif dalaam lingkungannya yaang menghasilkan perubahan-perubahan dalaam pengetahuan, pemahaman, keterampilan, dan nilai sikap.

Berdasarkan dari beberapa definisi prestasi dan belajar di atas, dapat disimpulkan bahwa prestasi belajar adalah kemampuan atau kecerdasan seseorang dalaam mensukseskan suatu tujuan, sehinngga tujuan itu jelas dan menentukan (Adinugroho,1997). Djamarah (1994) dalaam (Yeni Rahmawati,2006) menyatakan prestasi belajar adalah hasil yaang diperoleh berupa kesan-kesan yaang mengakibatkan perubahan dalaam diri individu sebagai hasil dari aktivitas dalaam belajar. Prestasi belajar juga dapat dikatakan sebagai suatu keadaan dimana siswa telah memperoleh hasilnya dari proses belajar. Proses belajar ini dalaam rangka untuk merubah sikap dan dapat menyesuaikan diri terhdap keadaan sekitarnya sebagi sumber belajar.

\section{Faktor-faktor yaang mempengaruhi prestasi belajar}

Prestasi belajar merupakan hal yaang kompleks. Siswalah yaang menentukan terjadi atau tidak terjadinya belajar. Terjadinya proses belajar timbul suatu aktivitas pengalaman belajar. Faktor-faktor yaang mempengaruhi prestasi belajar ada dua faktor, pertama faktor internal yaitu, keadaan / kondisi jasmani dan rohani siswa dan kedua faktor eksternal, yaitu kondisi lingkungan / di luar siswa. Faktor intern yaitu faktor yaang ada dalaam diri individu yaang sedang belajar.

1. Faktor Internal

a. Faktor fisiologis, yaitu meliputi segala hal yaang berhubungan dengn keadaan fisik / jasmani individu seseorang, dan pada umumnya sangat berpengaruh terhdap kemampuan belajar seseorang. Menurut Noehi Nasution,dkk dalaam Syaiful Bahri Djamarah, bahwa " orang yaang dalaam keadaan segar jasmaninya berlainan belajarnya dari orang yaang dalaam keadaan kelelahan ". Anak-anak yaang kekurangan gizi, mereka lekas lelah, mudah mengantuk, dan sukar menerima atau memperhatikan pelajaran.

b. Faktor Fisiologis

1. Kecerdasan / Intelegensi

Menurut Chaplin dalaam Slameto intelegensi adalah kecakapan yaang terdiri dari tiga jenis yaitu kecakapan untuk menghadapi dan menyesuaikan ke dalaam situasi yaang baru dengn cepat dan efektif, mengetahui relasi dan mempelajarinya dengn cepat. Intelegensi besar pengaruhnya terhdap kemajuan belajar, dalaam situasi yaang sama, siswa yaang mempunyai tingkat intelegensi yaang tinggi akan lebih berhasil daripada siswa yaanga mempunyai tingkat intelegensi yaang rendah.

\section{Minat}

Minat adalah suatu rasa lebih suka dan rasa ketertarikan pada suatu hal atau aktivitas tanpa ada yaang mempengaruhinya. Minat besar pengaruhnya terhdap belajar, karena bahan pelajaran yaang dipelajari tidak sesuai dengn minat siswa, maka mereka tidak akan belajar dengn sebaik-baiknya, karena tidak ada daya tarik baginya. Sebaliknya, bahan pelajaran yaang menarik minat siswa, lebih mudah dipelajari dan disimpan karena minat menambah kegiatan belajar.

3. Motivasi 
" Eysenck dan kawan-kawan dalaam Slameto merumuskan motivasi sebagai suatu proses yaang menentukan tingkah dan kegiatan, intensitas, konsistensi serta arah umum dari tingkah laku manusia ". Pelajar yaang termotivasi mempunyai harapan untuk memperoleh hasil belajar yaang lebih baik, karena ia menyadari di dalaam ilmu pengetahuan yaang dipelajarinya terkandung nilai-nilai yaang bermanfaat untuk dirinya, sehinngga tumbuh kemauan dan ketekunan dalaam dirinya serta selalu berusaha untuk sampai pada prestasi yaang optimal, begitu juga sebaliknya.

4. Perhatian

Perhatian merupakan keaktifan jiwa yaang dipertinggi, jiwa itu pun semata mata tertuju pada suatu benda / hal atau sekumpulan objek. Agar siswa dapat belajar dengn baik, guru hendaknya dapat membuat situasi dan bahan pelajaran yaang bisa menarik perhatian dengn cara bahan pelajarannya itu disesuaikan dengn kondisi yaang ada.

5. Kesiapan

Kesiapan atau readiness menurut Drever dalaam Slameto adalah kesediaan untuk member respon atau bereaksi. Kesiapan itu perlu diperhatikan dalaam proses belajar, karena jika siswa belajar dan padanya sudah ada kesiapan, maka hasil belajarnya akan lebih baik.

2. Faktor Ekstern

a. Faktor Sekolah

Faktor sekolah yaang mempengaruhi belajar itu mencakup metode mengajar / model pembelajaran yaang dikembangkan, kurikulum, relasi siswa dengn guru, relasi siswa dengn siswa, disiplin sekolah, pelajaran, dan waktu sekolah, standar pelajaran, keadaan gedung, tata ruang belajar mengajar dan tugas rumah.

\section{Pembelajaran Kooperatif Tipe STAD}

Tipe ini dikembangkan oleh Slavin, dan merupakan salah satu tipe kooperatif yaang menekankan pada adanya aktivitas dan interaksi diantara siswa untuk saling memotivasi dan saling membantu dalaam menguasai materi pelajaran guna mencapai kriteria yaang maksimal (Isjoni, 2009). Pada proses pembelajarannya, belajar kooperatif tipe STAD melalui 5 tahapan berikut ini :

\section{a. Penyajian Materi}

Pada tahap ini guru memulai menyampaikan indikator yaang harus dicapai hari itu dan memotivasi rasa ingin tahu siswa tentang materi yaang akan dipelajari, dalaam penelitian ini adalah materi tentang Gerak. Kemudian dilanjutkan dengn memberi persepsi dengn tujuan mengingatkan siswa terhdap materi prasyarat yaang telah dipelajari, agar siswa dapat menghubungkan materi yaang akan disajikan dengn pengetahuan yaang telah dimiliki. Mengenai teknik penyajian materi pembelajaran dapat dilakukan secara klasikal ataupun secara audiovisual. Lamanya presentasi dan beberapa kali harus dipresentasikan bergantung pada keberhasilan pada materi yaang akan dibahas.

Dalaam mengembangkan materi pembelajaran perlu ditekankan hal-hal sebagai berikut :

1) Mengembangkan materi pembelajaran sesuai dengn apa yaang akan dipelajari siswa dalaam kelompok.

2) Menekankan bahwa belajar adalah memahami makna, dan bukan hafalan. 
3) Memberikan umpan balik sesering mungkin untuk mengontrol pemahaman siswa.

4) Memberikan penjelasan mengapa jawaban pertanyaan itu benar atau salah.

5) Beralih kepada materi selanjutnya apabila siswa telah memahami permasalahan yaang ada.

\section{b. Kerja Kelompok}

Pada tahap ini setiap siswa diberi lembar tugas sebagai bahan yaang akan dipelajari. Dalaam kerja kelompok setiap siswa saling berbagi tugas, saling membantu memberikan penyelesaian agar anggota semua kelompok dapat memahami materi yaang dibahas, dan satu lembar dikumpulkan sebagai hasil kerja kelompok. Pada tahap ini guru berperan sebagai fasilitator dan motivator kegiatan tiap kelompok.

\section{c. Tes Individu}

Untuk mengetahui sejauh mana keberhasilan belajar telah dicapai, diadakan tes secara individual, mengenai materi yaang telah dibahas. Pada penelitian ini, tes individual diadakan pada akhir pertemuan kedua dan ketiga, masing-masing selama 10 menit agar siswa dapat menunjukkan apa yaang telah dipelajari secara individual selama bekerja dalaam kelompok. Skor perolehan individu ini didata dan diarsipkan, yaang akan digunakan pada perhitungan perolehan skor kelompok.

\section{d. Perhitungan Skor Perkembangan Individu}

Perhitungan skor perkembangan individu dihitung berdasarkan skor awal, dalaam penelitian ini didasarkan pada nilai evaluasi hasil belajar semester 1 (satu). Berdasarkan skor awal setiap siswa memiliki kesempatan yaang sama untuk memberikan sumbangan skor maksimal bagi kelompoknya berdasarkan skor tes yaang diperolehnya. Penghitungan perkembangan skor individu dimaksud agar siswa terpacu untuk memperoleh prestasi terbaik sesuai dengn kemampuannya. Adapun penghitungan skor perkembangan individu pada penelitian ini diambil dari penskoran perkembangan individu yaang dikemukakan slavin (1995) dalaam Isjoni (2009), seperti terlihat pada tabel berikut ini:

\section{e. Pemberian Penghargaan Kelompok}

Pemberian penghargaan diberikan berdasarkan perolehan skor rata-rata yaang dikategorikan menjadi kelompok baik, kelompok hebat dan kelompok super. Adapun kriteria yaang digunakan untuk menentukan pemberian penghargaan terhdap kelompok adalah sebagai berikut:

1) Kelompok dengn skor rata-rata 15 , disebut sebagai kelompok baik.

2) Kelompok dengn skor rata-rata 20, disebut sebagai kelompok hebat.

3) Kelompok dengn skor rata-rata 25 disebut sebagai kelompok super.

\section{Penggunaan Alat Peraga dalaam Pembelajaran Matematika}

Pada dasarnya secara individual manusia itu berbeda-beda. Demikian pula dalaam memahami konsep-konsep abstrak akan dicapai melalui tingkat-tingkat belajar yaang berbeda. Suatu keyakinan bahwa anak belajar melalui dunia nyata menuju ke dunia abstrak dengn memanipulasi benda-benda nyata dapat digunakan sebagai perantaranya. Setiap konsep abstrak dalaam matematika yaang baru dipahami anak perlu segera diberikan penguatan supaya mengendap, melekat, dan tahan lama tertanam, sehinngga menjadi miliknya dalaam pola pikir maupun pola tindakan. 
Alat peraga adalah suatu alat yaang dapat diserap oleh mata dan telinga dengn tujuan membantu guru agar proses belajar mengajar siswa lebih efektif dan efisien (Sudjana,2002:59)

Alat peraga dalaam mengajar memegang peranan penting sebagai alat bantu untuk menciptakan proses belajar mengajar yaang efektif. Proses belajar mengajar ditandai dengn beberapa unsur antara lain tujuan, bahan, metode, dan alat serta evaluasi. Unsur metode dan alat merupakan unsure yaang tidak dapat dilepaskan dari unsur lainnya yaang berfungsi sebagai cara atau tehnik untuk mengantarkan sebagai bahan pelajaran agar sampai tujuan. Dalaam pencapaian tersebut, peranan alat bantu atau alat peraga memegang peranan yaang penting, sebab dengn adanya alat peraga ini materi dengn mudah dapat dipahami oleh siswa. Alat peraga sering disebut audio visual, dari pengertian alat yaang dapat diserap oleh mata dan telinga. Alat tersebut berguna agar apelajaran yaang disampaikan guru lebih mudah dipahami oleh siswa. Dalaam proses belajar mengajar alat peraga dipergunakan dengn tujuan membantu guru agar proses belajar siswa lebih efektif dan efisien. Alat peraga merupakan bagian dari media pendidikan, penggunaannya diintegrasikan dengn tujuan dan isi pengajaran yaang telah dituangkan dalaam Garis Besar Program Pengajaran (GBPP) mata pelajaran matematika dan bertujuan untuk mempertinggi mutu kegiatan belajar mengajar.

\section{METODE PENELITIAN}

\section{Jenis Penelitian}

Jenis penelitian ini adalah Penelitian Tindakan Kelas (PTK). Penelitian tindakan kelas merupakan suatu pencermatan terhdap kegiatan yaang sengaja dimunculkan dan terjadi di dalaam kelas. Keunggulan penelitian ini adalah guru diikutsertakan dalaam penelitian sebagai subjek yaang melakukan tindakan, yaang diamati, sekaligus diminta untuk merefleksi hasil pengamalan selama melakukan tindakan tentu lama kelamaan akan terjadi perubahan dalaam diri mereka suatu kebiasaan untuk mengevaluasi diri (Suharsimi,2006).

\section{Pendekatan Penelitian}

Pendekatan yaang digunakan dalaam penelitian ini adalah pendekatan kualitatif dan pendekatan kuantitatif.

1. Pendekatan kualitatif adalah suatu proses yaang digunakan peneliti untuk mendapatkan data berupa informasi berbentuk pernyataan yaang memberi gambaran tentang ekspresi siswa yaang berkaitan dengn tingkat pemahaman terhdap suatu mata pelajaran, perhatian, serta motivasi belajar siswa.

2. Pendekatan kuantitatif adalah suatu proses yaang digunakan peneliti untuk mendapatkan data berupa angka dari hasil evaluasi siswa yaang dapat dihitung dengn analisis statistik deskriptif.

\section{Rancangan Penelitian}

Rancangan penelitian yaang dimaksud adalah berupa penggunaan alat peraga terhdap peningkatan aktivitas dan prestasi belajar siswa kelas VIIA SMPN 2 Madapangga Tahun Pelajaran 2018/2019.

Penelitian ini akan dilaksanakan dalaam dua siklus. Setiap siklus terdiri dari empat tahap, yaitu : perencanaan, pelaksanaan, observasi, dan refleksi. Menurut 
Arikunto (2008) ada empat tahapan yaang lazim dilalui dalaam penelitian tindakan kelas, yaitu (1) perencanaan, (2) pelaksanaan, (3) pengamatan, dan (4) refleksi.

1. Siklus I

a. Perencanaan

1) Menyiapkan rencana pembelajaran.

2) Menyiapkan skenario pembelajaran.

3) Menyusun lembar kerja siswa (LKS) sebagai bahan pembelajaran siswa.

4) Membuat lembar observasi.

5) Menyusun alat evaluasi dalaam bentuk essay dan merencanakan analisis hasil tes.

6) Membuat pedoman penilaian.

7) Media/ alat yaang dibutuhkan.

b. Pelaksanaan tindakan

Dalaam tahap ini pelaksanaan tindakan yaang dilakukan adalah kegiatan belajar mengajar yaang telah direncanakan dalaam rencana pembelajaran.

c. Observasi dan Evaluasi

Dalaam melakukan observasi akan diamati kegiatan guru dan kegiatan siswa yaang tampak selama pelaksanaan tindakan, serta apakah kegiatan pembelajaran yaang dilaksanakan sesuai dengn rencana pembelajaran yaang telah dibuat. Semua aktivitas tersebut dicatat dalaam lembar observasi yaang telah disiapkan. Pada akhir siklus dilakukan evaluasi hasil belajar untuk mengetahui pemahaman atau penguasaan siswa terhdap konsep-konsep yaang telah dipelajari. Dalaam penelitian ini yaang bertindak sebagai observer/pengamat adalah peneliti.

d. Refleksi

Hasil yaang diperoleh dari observasi dan evaluasi belajar siswa dikumpulkan serta dianalisa, sehinngga pada tahap ini peneliti bersama guru dapat merefleksi diri dengn melihat data observasi dan hasil evaluasi belajar siswa serta mengidentifikasikan kekurangan dan menganalisis sebab kekurangan. Hasil refleksi ini digunakan sebagai dasar untuk perbaikan serta penyempurnaan perencanaan dan pelaksanaan tindakan pada siklus berikutnya.

\section{Siklus II}

Siklus II dilakukan jika refleksi siklus I memperoleh hasil yaang kurang optimal. Langkah-langkah yaang dilakukan pada siklus II pada dasarnya sama dengn langkah-langkah pada siklus I, akan tetapi pada siklus II akan dilakukan perbaikan terhdap kekurangan-kekurangan pada siklus I.

\section{Instrumen Penelitian}

Instrumen penelitian adalah alat untuk memperoleh data. Alat ini harus dipilih sesuai dengn jenis data yaang diinginkan. Instrumen sebagai alat pengumpul data pada hakikatnya adalah mengukur variabel penelitian. Instrumen yaang lazim digunakan dalaam penelitian antara lain kuesioner, observasi, dan tes (Nana Sudjana, 1999:58). Sejalan dengn pendapat di atas, Sugiyono (2009: 101) menyatakan instrumen penelitian adalah suatu alat yaang digunakan mengukur fenomena alam maupun sosial yaang diamati. Secara spesifik semua fenomena ini disebut variabel penelitian. Berdasarkan pendapat para ahli di atas, maka instrumen penelitian yaang digunakan adalah sebagai berikut. 
1. Rencana Pelaksanaan Pembelajaran (RPP)

Rencana pelaksanaan pembelajaran (RPP) adalah rencana yaang menggambarkan prosedur dan manajemen pembelajaran untuk mencapai suatu atau lebih kompetensi dasar yaang ditetapkan dalaam standar isi dan dijabarkan dalaam silabus. RPP pada hakekatnya merupakan perncanaan jangka pendek untuk memperkirakan atau memproyeksikan apa yaang akan dilakukan dalaam pembelajaran (Mulyasa, 2007: 183-184).

2. Skenario Pembelajaran

Skenario pembelajaran adalah langkah-langkah yaang akan dilakukan dalaam proses pembelajaran.

3. Tes

Sebelum adanya Ejaan Yaang Disempurnakan dalaam bahasa Indonesia ditulis dengn test), adalah merupakan alat atau prosedur yaang digunakan untuk mengetahui atau mengukur sesuatu dalaam suasana, dengn cara dan aturan-aturan yaang sudah ditentukan (Arikunto, 2009: 53). Sedangkan, menurut Iskandar (2009: 234) tes adalah suatu cara untuk mengadakan penilaian yaang berbentuk suatu tugas atau serangkaian tugas yaang harus dikerjakan oleh anak atau sekelompok anak sehinngga menghasilkan suatu nilai tentang tingkah laku atau prestasi anak tersebut.

Lebih lanjut Fathurrohman dan Sutikno (2007: 77) mendefinisikan tes sebagai alat pengukuran berupa pertanyaan, perintah, dan petunjuk yaang ditujukan kepada testee untuk mendapatkan respon sesuai dengn petunjuk itu. Jenis tes yaang digunakan dalaam penelitian ini adalah tes subjektif, dimana tes tersebut berupa pertanyaan atau suatu suruhan yaang menghendaki jawaban berupa uraian-uraian.

4. Lembar Observasi

Menurut Sutrisno (1986) dalaam Sugiyono (2010: 145) mengemukakan bahwa, observasi merupakan suatu proses yaang kompleks, suatu proses yaang tersusun dari pelbagai proses biologis dan psikhologis. Dua di antara yaang terpenting adalah proses-proses pengamatan dan ingatan. Pendapat lain, menurut Nurkancana dan Sunartana (1990:51), observasi adalah suatu cara untuk mengadakan penilaian dengn jalan mengadakan pengamatan secara langsung dan sistematis. Data-data yaang diperoleh dalaam observasi itu dicatat dalaam catatan observasi. Secara umum, observasi dapat diartikan sebagai penghimpunan bahan-bahan keterangan yaang dilakukan dengn mengadakan pengamatan dan pencatatan secara sistematis terhdap berbagai fenomena yaang dijadikan objek pengamatan. Untuk melaksanakan observasi bisa dilakukan secara langsung oleh observer (observasi langsung), bisa melalui perwakilan atau perantara, baik teknik maupun alat tertentu (observasi tidak langsung). Adapun isi dari observasi adalah kegiatan guru dan motivasi siswa atau kegiatan siswa selama proses belajar mengajar berlangsung. Jenis alat obervasi yaang digunakan daftar cek, dimana pendataan data dilakukan dengn mempergunakan sebuah daftar yaang memuat nama observer disertai jenis gejala yaang diamati.

\section{Teknik Pengumpulan Data}

Teknik pengumpulan data dalaam penelitian ini adalah:

1. Sumber Data

Yaang dimaksud dengn sumber data dalaam penelitian adalah subjek dari mana data dapat diperoleh (Suharsimi,2006). Dalaam penelitian ini data berasal dari 16 siswa, guru sebagai pengajar, dan peneliti sebagai observer.

2. Jenis Data 
a. Data Kualitatif

Data yaang diperoleh dari hasil observasi aktivitas siswa dan guru dalaam proses belajar mengajar.

b. Data Kuantitatif

Data yaang diperoleh berupa skor yaang dihasilkan dari tes yaang diberikan pada setiap akhir pembelajaran.

3. Cara Pengumpulan Data

a. Data tentang situasi belajar mengajar diperoleh dari lembar observasi.

b. Data tentang hasil belajar diperoleh dengn cara memberikan tes evaluasi atau ulangan pada siswa setiap akhir siklus.

\section{Teknik Analisis Data}

Analisa data adalah proses mencari dan menyusun secara sistematis data yaang diperoleh dari hasil wawancara, catatan lapangan, dan dokumentasi, dengn cara mengorganisasikan data ke dalaam kategori, menjabarkan ke dalaam unit-unit, melakukan sintesa, menyusun ke dalaam pola, memilih mana yaang penting dan yaang akan dipelajari, dan membuat kesimpulan sehinngga mudah dipahami oleh diri sendiri maupun orang lain (Sugiyono, 2010: 244). Data hasil penelitian tindakan kelas ini dikumpulkan dan dianalisis dengn cara sebagai berikut.

1. Data Aktivitas Siswa

Data aktivitas siswa dianalisis dengn cara sebagai berikut:

a. Menentukan skor yaang diperoleh siswa:

Skor 4 diberikan jika $\geq 75 \%$ dan $<100 \%$ siswa melakukan deskriptor

Skor 3 diberikan jika $\geq 51 \%$ dan $<75 \%$ siswa melakukan deskriptor

Skor 2 diberikan jika $\geq 25 \%$ dan $<50 \%$ siswa melakukan deskriptor

Skor 1 diberikan jika $\geq 0 \%$ dan $<25 \%$ siswa melakukan deskriptor

b. Menentukan skor Mean Ideal (MI) dan Standar Deviasi Ideal (SDI)

$$
\begin{aligned}
& \mathrm{MI}=1 / 2 \times(\text { skor maksimal }+ \text { skor minimal }) \\
& \mathrm{SDI}=1 / 6 \times(\text { skor maksimal }- \text { skor minimal })
\end{aligned}
$$

Keterangan:

MI $=$ Mean Ideal (angka rata-rata ideal)

SDI $\quad=$ Standar Deviasi Ideal

(Nurkencana dan Sunartana, 1999).

c. Menentukan skor rata-rata aktivitas belajar siswa

$$
\mathrm{AS}=\frac{\sum \mathrm{x}}{\mathrm{i}}
$$

Keterangan :

AS : skor rata-rata aktivitas belajar siswa

$\sum \mathrm{x}$ : Jumlah skor aktivitas belajar siswa

i : banyaknya deskriptor

Kriteria untuk menentukan aktivitas belajar siswa sebagai berikut:

2. Data Aktivitas Guru

Pengolahan data dilakukan dengn mengobsevasi aktivitas guru sesudah menggunakan alat peraga. Data aktivitas guru dianalisis dengn cara sebagai berikut.

a. Menentukan skor yaang diperoleh guru:

Skor 4 diberikan jika semua deskriptor nampak

@ 2020 DIKSI (https://jurnal.bimaberilmu.com/index.php/diksi) 
Skor 3 diberikan jika 2 deskriptor nampak

Skor 2 diberikan jika 1 deskriptor nampak

Skor 1 diberikan jika tidak ada deskriptor nampak

b. Menentukan MI dan SDI

$\mathrm{MI}=1 / 2 \times($ skor maksimal + skor minimal $)$

$\mathrm{SDI}=1 / 6 \mathrm{x}$ (skor maksimal - skor minimal $)$

Keterangan :

MI $=$ Mean Ideal (angka rata-rata ideal)

SDI $\quad=$ Standar Deviasi Ideal

(Nurkencana dan Sumartana, 1999).

c. Menentukan rata-rata aktivitas guru

$\mathrm{AG}=\frac{\sum \mathrm{x}}{\mathrm{i}}$

Keterangan :

AG : skor rata-rata aktivitas guru

$\sum \mathrm{x}$ : Jumlah skor aktivitas guru

$\mathrm{i}$ : banyaknya deskriptor

Kriteria untuk menentukan aktivitas guru sebagai berikut:

3. Data Tes Hasil Belajar

Setelah memperoleh data tes hasil belajar, maka data tersebut dianalisa dengn mencari nilai rata-rata kelas dan ketuntasan belajar. Untuk mengetahui tingkat keberhasilan belajar, digunakan kriteria sebagai berikut:

a. Rata-rata Kelas

Untuk menghitung nilai rata-rata kelas digunakan rumus sebagai berikut (Nurkancana dan Sunartana, 1990: 173-174):

$\mathrm{M}=\frac{\sum X}{N}$

\section{Keterangan:}

$\mathrm{M} \quad=$ Mean (nilai rata-rata)

$\sum \mathrm{X} \quad=$ Jumlah nilai yaang diperoleh siswa

$\mathrm{N}=$ Jumlah individu/ siswa yaang ikut tes

b. Ketuntasan Individu

Hal-hal yaang harus diperhatikan dalaam penentuanKriteria Ketuntasan Minimal (KKM) adalah:

1) Tingkat kompleksitas, kesulitan setiap indikator, kompetensi dasar, dan standar kompetensi yaang harus dicapai oleh peserta didik.

2) Kemampuan sumber daya pendukung dalaam penyelenggaraan pembelajaran pada masing-masing sekolah.

3) Tingkat kemampuan (Intake) rata-rata peserta didik di sekolah yaang bersangkutan (Depdiknas, 2008),

(http://aadesanjaya.blogspot.com).

Berdasarkan uraian di atas ketuntasan individu ditentukan berdasarkan tingkar kompleksitas (kesulitan), Sarana dan prasarana, dan tingkat kemampuan siswa. Nilai ketuntasan minimal di SMPN 2 Madapangga adalah $\geq 65$.

c. Ketuntasan Klasikal 
Menurut Mulyasa (2007: 254) keberhasilan kelas dilihat dari jumlah peserta didik yaang mampu menyelesaikan atau mencapai Kriteria Ketuntasan Minimal, sekurang-kurangnya $85 \%$ dari jumlah peserta didik yaang ada di kelas tersebut. Senada dengn pendapat di atas, Saidiharjo, (1991: 9) dalaam Suryosubroto (2002: 55-56) menyatakan bahwa taraf penguasaan minimal kelompok yaang $85 \%$ dari jumlah siswa dalaam kelompok yaang bersangkutan telah memenuhi kriteria ketuntasan.

Jadi, persentase ketuntasan kelompok/ klasikal (keseluruhan) dapat diperoleh dengn rumus ketuntasan belajar klasikal, yaitu sebagai berikut:

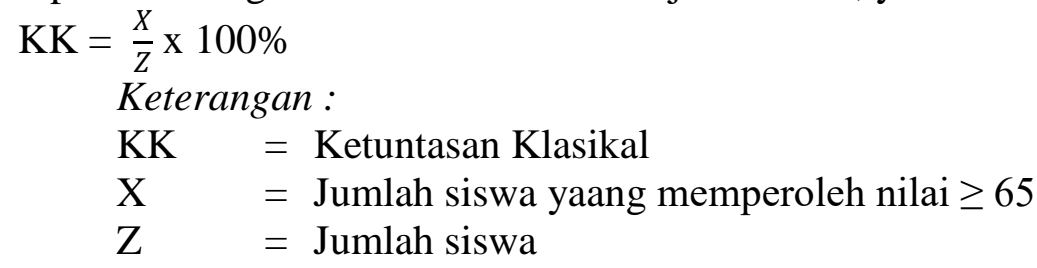

\section{HASIL DAN PEMBAHASAN}

\section{Hasil Penelitian}

Proses pelaksanaan dan hasil penelitian yaang telah dilakukan pada tiap-tiap siklus akan diuraikan sebagai berikut :

\section{Siklus I}

Pelaksanaan penelitian untuk siklus I berlangsung masing-masing dua kali pertemuan. Masing-masing pertemuan berlangsung selama 2 × 45 menit. Untuk lebih jelasnya, tindakan yaang dilakukan pada siklus I dipaparkan sebagai berikut :

a. Perencanaan

Sebelum dilaksanakan pembelajaran pada siklus I, terlebih dahulu peneliti mempersiapkan hal-hal pokok, sebagai berikut :

1. Rencana pelaksanaan pembelajaran

2. Skenario pembelajaran

3. Lembar Kegiatan Siswa (LKS)

4. Alat Peraga

5. Lembar observasi aktivitas siswa

6. Lembar observasi aktivitas guru

7. Soal tes evaluasi

8. Pedoman penskoran tes evaluasi

9. Analisis hasil tes evaluasi

10. Koordinasi dengn guru kelas yaang bertindak sebagai observer dalaam proses pembelajaran.

b. Pelaksanaan Tindakan

Kegiatan yaang dilakukan pada tahap ini adalah melaksanakan rencana pelaksanaan pembelajaran siklus I. Pelaksanaan pembelajaran pada pertemuan I, guru mengecek kehadiran siswanya. Jumlah keseluruhan siswa di kelas VIIA ada 16 orang, 1 siswa pindah sekolah, 2 tidak masuk tanpa keterangan dan 1 siswa tidak masuk karena sakit. Total siswa yaang mengikuti pelajaran adalah 12 orang.

Sebelum guru menyampaikan pokok materi, siswa diminta menyebutkan nama-nama hewan berkaki empat, unggas, siswa yaang ada di kelas VIIA. Siswa antusias menyebutkannya, tanpa memperdulikan jawabannya benar atau salah. 
Ada siswa yaang menyebutkan kucing termasuk unggas. Kemudian guru meluruskan maksud dari yaang disampaikan oleh siswa tersebut.

Guru menjelaskan pengertian himpunan, yaang termasuk himpunan, anggota dari himpunan, dan yaang bukan himpunan. Guru meminta siswa bergantian untuk menuliskan di papan tulis contoh himpunan dan anggotanya dalaam kehidupan sehari-hari. Namun ada siswa yaang masih malu dan takut salah untuk mengerjakan soal. Guru memotivasi dengn memberikan reward bagi siswa yaang berani maju mengerjakan soal di papan tulis meskipun jawabannya belum benar.

Pada penyampaian materi notasi himpunan, beberapa siswa belum terbiasa menulis notasi dari himpunan.Guru melanjutkan ke materi himpunan berhingga dan tak hingga. Siswa mulai bersemangat dalaam mengerjakan soal yaang diberikan oleh guru di papan tulis. Guru memberikan soal yaang dikerjakan secara kelompok, namun tiap anggotanya harus memberikan jawaban secara tertulis kepada ketua kelompoknya. Guru menunjuk perwakilan dari anggota kelompok masing-masing secara bergantian. Hal ini dilakukan agar siswa paham akan materi yaang sedang dipelajari.

Guru mengenalkan alat peraga, menjelaskan bahan-bahan yaang digunakan dan cara penggunaannya. Para siswa memperhatikan secara seksama, namun masih ada siswa yaang ngobrol dengn temannya. Siswa diminta untuk mencoba menggunakan alat peraga secara bergantian meskipun masih perlu dampingan.

Sebelum mengakhiri pelajaran guru memberikan kesempatan kepada siswa untuk menyimpulkan dari materi yaang telah dipelajari. Namun hanya ada 5 orang yaang berani mengutarakan pendapatnya. Guru menyimpulkan materi yaang telah disampaikan dan memberikan tugas di rumah.

Pelaksanaan pembelajaran pertemuan kedua diikuti oleh 12 orang dan semua siswa masuk kelas tepat waktu. Siswa telah menyiapkan kelengkapan belajarnya. Sebelum menyampaikan materi berikutnya, guru dan siswa membahas tugas yaang diberikan. Tiap siswa diberi kesempatan untuk menjawab. Masih ada siswa yaang menjawab ragu-ragu. Guru menyarankan agar siswa memperbaiki jawaban yaang salah. Pada pertemuan kedua ini guru menyampaikan materi himpunan kosong, nol beserta notasinya dan himpunan semesta beserta anggotanya. Siswa terlihat lebih bersemangat dalaam mengikuti pelajaran. Dapat dilihat dari cara siswa menjawab pertanyaan dari guru yaang begitu antusias, sehinngga suasana kelas lebih hidup dibanding sebelumnya. Kegiatan diskusi berkelompok lebih kompak dibanding sebelumnya meskipun masih ada 1 atau 2 orang yaang kurang aktif.

Guru memberikan latihan soal. Tiap-tiap siswa menulis jawabannya di buku tulis, setelah itu dipraktekan dengn menggunakan alat peraga masing-masing. Pada kegiatan ini siswa sudah terlihat mandiri dalaam menggunakan alat peraga. Bahkan diantaranya menjadi guru damping di kelompok lain. Siswa terlihat lebih rileks dalaam mengerjakan soal.

c. Observasi Tindakan

1. Observasi Aktivitas Siswa

1. Kesiapan siswa dalaam menerima pelajaran

2. Pengenalan alat peraga (blok himpunan) yaang akan digunakan.

3. Kemampuan siswa menggunakan alat peraga (blok himpunan) dalaam menyelesaikan soal. 
4. Berdiskusi dan bekerjasama.

5. Menyimpulkan materi.

Tabel 3. Data hasil observasi aktivitas siswa siklus I

\begin{tabular}{|l|c|c|}
\hline Pertemuan & 1 & 2 \\
\hline Skor aktivitas siswa & 14,9 & 17 \\
\hline Kategori & Aktif & Sangat aktif \\
\hline
\end{tabular}

Tabel di atas menunjukkan bahwa indikator keberhasilan tercapai pada siklus I pertemuan ke 2. Namun ada beberapa poin di indikator keberhasilan yaang perlu ditingkatkan sehinngga dilanjutkan ke siklus II. Dari hasil observasi aktivitas belajar siswa selama proses pembelajaran pada siklus I dapat dilihat sebagai berikut :

- Siswa masih belum berani bertanya tentang materi yaang belum dipahami.

- Siswa masih ragu mengungkapkan kesimpulan dengn bahasanya sendiri.

2. Observasi Aktivitas Guru

Dalaam proses pembelajaran di kelas, guru melaksanakan kegiatan belajar mengajar sesuai rencana pelaksanaan pembelajaran yaang telah direncanakan, yaitu menggunakan alat peraga untuk meningkatkan aktivitas dan prestasi belajar matematika. Data tentang hasil observasi aktivitas guru siklus I pertemuan 1 dan pertemuan 2 sebagai berikut :

1. Membuka proses pembelajaran.

2. Menciptakan suasana kelas yaang kondusif.

3. Membangkitkan minat dan motivasi belajar.

4. Menyelesaikan soal dengn alat peraga.

5. Mendampingi siswa dalaam diskusi.

6. Membimbing siswa membuat kesimpulan hasil diskusi.

Tabel 4. Data hasil analisis observasi aktivitas guru siklus I

\begin{tabular}{|l|c|c|}
\hline Pertemuan & 1 & 2 \\
\hline Skor aktivitas guru & 22 & 23 \\
\hline Kategori & Sangat baik & Sangat baik \\
\hline
\end{tabular}

Berdasarkan hasil observasi, aktivitas guru yaang belum terlaksana dengn baik adalah sebagai berikut :

- Guru belum menyampaikan tujuan pembelajaran.

- Guru belum bisa mengkondisikan suasana kelas yaang mengganggu proses belajar mengajar.

3. Prestasi Belajar Siswa

Data tentang hasil evaluasi belajar siswa pada siklus I adalah sebagai berikut :

Tabel 5. data hasil analisis evaluasi belajar siswa siklus I

\begin{tabular}{|l|c|}
\hline Jumlah siswa yaang mengikuti tes & 11 \\
\hline K K M & 65 \\
\hline Jumlah siswa yaang tuntas & 7 \\
\hline Jumlah siswa yaang tidak tuntas & 4 \\
\hline Nilai tertinggi & 100 \\
\hline
\end{tabular}




\begin{tabular}{|l|c|}
\hline Nilai terendah & 40 \\
\hline Rata-rata & 77,09 \\
\hline Persentase ketuntasan klasikal & $63,64 \%$ \\
\hline
\end{tabular}

Berdasarkan tabel di atas, ketuntasan belajar siswa secara klasikal adalah 63,64\% hal ini menunjukkan bahwa ketuntasan klasikal belum mencapai standar ketuntasan minimal yaitu $85 \%$, ini berarti indikator keberhasilan untuk prestasi belajar siswa belum tercapai. Dari tabel di atas terdapat 4 orang siswa yaang tidak tuntas disebabkan kesulitan dalaam menjawab soal 3 dan 4 yaang berkaitan dengn mendaftar anggota himpunan dan himpunan kosong.

d. Refleksi

Berdasarkan hasil observasi yaang diperoleh selama pelaksanaan siklus I, masih terdapat beberapa kekurangan yaang harus diperbaiki di siklus II yaitu sebagai berikut :

- Guru belum menyampaikan tujuan pembelajaran.

- Guru belum bisa mengkondisikan suasana kelas yaang mengganggu proses belajar mengajar.

\section{Siklus II}

Pelaksanaan penelitian untuk siklus II berlangsung masing-masing dalaam dua kali pertemuan. Pertemuan I berlangsung selama 2 x 45 menit pada tanggal 12 Januari 2012 . Pertemuan II berlangsung selama 2 x 45 menit untuk penyampaian materi dan evaluasi pada tanggal 13 Januari 2012. Untuk lebih jelasnya, tindakan yaang dilakukan pada siklus II akan dipaparkan sebagai berikut :

a. Perencanaan

Sebelum dilaksanakan pembelajaran pada siklus II, terlebih dahulu peneliti mempersiapkan hal-hal pokok sebagai berikut :

1. Rencana pelaksanaan pembelajaran

2. Skenario pembelajaran

3. Lembar Kegiatan Siswa (LKS)

4. Alat Peraga

5. Lembar observasi aktivitas siswa

6. Lembar observasi aktivitas guru

7. Soal tes evaluasi

8. Pedoman penskoran tes evaluasi

9. Analisis hasil tes evaluasi

10. Koordinasi dengn guru kelas yaang bertindak sebagai observer dalaam proses pembelajaran.

b. Pelaksanaan Tindakan

Guru melaksanakan pembelajaran di kelas sesuai dengn rencana pelaksanaan pembelajaran siklus II dan melaksanakan perbaikan pada proses pembelajaran sesuai dengn refleksi. Pelaksanaan pembelajaran pertemuan I diikuti oleh 11 orang siswa dengn seluruh siswa adalah putra. Pada kegiatan pembelajaran ini siswa terlihat telah mempersiapkan diri, terlihat semua siswa masuk kelas dengn tertib dan tepat waktu.

Pada pertemuan I guru menyampaikan materi himpunan bagian. Siswa lebih bersemangat dan termotivasi dalaam proses pembelajaran saat ini. Terlihat 
dalaam menjawab soal yaang diberikan guru dengn menggunakan alat peraga, siswa berlomba-lomba ingin memberikan jawabannya.

Ketika diskusi berlangsung tiap-tiap kelompok lebih kompak dalaam menyelesaikan soal antar anggotanya. Adanya peningkatan dalaam mengemukakan pendapat dan memberikan tanggapan antar siswa. Pelaksanaan pembelajaran pada pertemuan 2, diikuti oleh 11 orang siswa. Semua siswa yaang hadir masuk kelas tepat waktu dan telah siap menerima pelajaran. Pertemuan kali ini guru menyampaikan materi irisan. Peningkatan yaang luar biasa terlihat pada siswa-siswa yaang ingin mencoba mengerjakan soal yaang diberikan guru dengn alat peraga di papan tulis. Bahkan ada yaang maju berkali-kali karena telah paham akan materi yaang dipelajari. Begitu antusiasnya para siswa dalaam mengerjakan soal-soal yaang diberikan oleh guru. Pada diskusi berkelompok tampak siswa berani mengungkapkan pendapatnya dan memperbaiki kesimpulan temannya yaang kurang tepat dengn bahasanya sendiri. Dengn alat peraga para siswa dapat belajar lebih rileks tanpa beban dan aktif dalaam mengikuti proses pembelajaran.

c. Observasi Tindakan

1. Observasi Aktivitas Belajar Siswa

Data tentang observasi aktivitas belajar siswa pada siklus II pertemuan I dan pertemuan II adalah sebagai berikut :

1. Kesiapan siswa dalaam menerima pelajaran

2. Pengenalan alat peraga (blok himpunan) yaang akan digunakan.

3. Kemampuan siswa menggunakan alat peraga (blok himpunan) dalaam menyelesaikan soal.

4. Berdiskusi dan bekerjasama.

5. Menyimpulkan materi.

Tabel 6. Data hasil observasi aktivitas belajar siswa siklus II

\begin{tabular}{|l|c|c|}
\hline Pertemuan & 1 & 2 \\
\hline Skor aktivitas siswa & 17,5 & 17,7 \\
\hline Kategori & Sangat aktif & Sangat aktif \\
\hline
\end{tabular}

Tabel di atas menunjukkan bahwa indikator keberhasilan untuk aktivitas belajar siswa pada siklus II telah tercapai.

2. Observasi Aktivitas Guru

Data tentang hasil observasi aktivitas guru siklus II pertemuan 1 dan pertemuan 2 adalah sebagai berikut :

1. Membuka proses pembelajaran.

2. Menciptakan suasana kelas yaang kondusif.

3. Membangkitkan minat dan motivasi belajar.

4. Menyelesaikan soal dengn alat peraga.

5. Mendampingi siswa dalaam diskusi.

6. Membimbing siswa membuat kesimpulan hasil diskusi.

Tabel 7. Data hasil observasi aktivitas guru siklus II

\begin{tabular}{|l|c|c|}
\hline Pertemuan & 1 & 2 \\
\hline Skor aktivitas guru & 24 & 24 \\
\hline Kategori & Sangat baik & Sangat baik \\
\hline
\end{tabular}


Berdasarkan tabel hasil observasi aktivitas guru di atas, terlihat bahwa guru sudah berhasil menggunakan alat peraga dalaam kegiatan pembelajaran.

3. Prestasi Belajar Siswa

Tabel 8. Data hasil tes evaluasi belajar siswa siklus II

\begin{tabular}{|l|c|}
\hline Jumlah siswa yaang mengikuti tes & 11 \\
\hline K K M & 65 \\
\hline Jumlah siswa yaang tuntas & 10 \\
\hline Jumlah siswa yaang tidak tuntas & 1 \\
\hline Nilai tertinggi & 100 \\
\hline Nilai terendah & 51 \\
\hline Rata-rata & 86,72 \\
\hline Persentase ketuntasan klasikal & $90,91 \%$ \\
\hline
\end{tabular}

Berdasarkan tabel di atas, ketuntasan belajar siswa secara klasikal adalah 90,91\% hal ini menunjukkan bahwa indikator keberhasilan untuk prestasi belajar siswa sudah tercapai karena ketuntasan klasikalnya melebihi standar ketuntasan mimimal yaitu $85 \%$. Dari tabel di atas terdapat 1 siswa yaang tidak tuntas disebabkan siswa kesulitan dalaam menjawab soal evaluasi

d. Refleksi nomor 1 dan 5 tentang membuat diagram venn.

Berdasarkan hasil observasi yaang diperoleh selama pelaksanaan siklus II, terlihat bahwa kegiatan belajar mengajar sudah berjalan dengn baik, dari segi aktivitas siswa yaang berkategori sangat baik, maupun dari aktivitas guru yaang berkategori sangat baik.

\section{Pembahasan}

Berdasarkan hasil evaluasi terlihat bahwa hasil evaluasi dari siklus I ke siklus II mengalami peningkatan. Tidak tercapainya ketuntasan belajar pada siklus I disebabkan oleh beberapa hal antara lain siswa mengalami kesulitan dalaam menyelesaikan soal tentang anggota himpunan. Hal ini disebabkan karena kemapuan dasar siswa dalaam memahami materi yaang telah disampaikan masih kurang dan ketika berlangsung diskusi masih terdapat siswa yaang tidak serius dan kurang konsentrasi dalaam mendiskusikan materi pelajaran serta banyak siswa yaang tidak berani bertanya pada guru meskipun sebenarnya masih belum paham dengn materi yaang disampaikan.

Pada siklus I nilai rata-rata siswa 77.09 terdapat 7 siswa yaang memperoleh nilai $\geq 65$ dan 4 siswa $<65$, sehinngga persentase ketuntasan klasikalnya 63,64\%. Skor aktivitas belajar siswa pada siklus I pertemuan 1 adalah 14,9 dengn kategori aktif dan pada pertemuan 2 adalah 17 dengn kategori sangat aktif.

Peran guru juga sangat menentukan untuk meningkatkan aktivitas dan prestasi belajar siswa, untuk mendapat hasil yaang optimal tentunya guru harus berani memperbaiki diri dari kesalahan yaang telah dilakukan dan meningkatkan hal-hal yaang masih dianggap kurang. Setelah melihat hasil yaang dicapai pada siklus I, baik dari aktivitas belajar siswa maupun dari prestasi belajar siswa belum mencapai indikator keberhasilan. Oleh karena itu, perlu tindakan perbaikan pada siklus II.

Berdasarkan refleksi terhdap siklus I maka pada siklus II diberikan tindakan pada pembelajaran dengn mengutamakan penyempurnaan dan memperbaiki kekurangan-kekurangan yaang terjadi pada siklus I. Tindakan yaang dimaksud 
adalah memberikan motivasi kepada siswa agar lebih aktif terlibat dalaam pelajaran sebelumnya, berani mencoba mengerjakan soal ke depan kelas dengn alat peraga, dan berani bertanya serta mengungkapkan pendapatnya dalaam diskusi.

Persentase ketuntasan klasikal pada siklus II sebesar 90,91\% dengn nilai ratarata 86,72. Skor aktivitas siswa siklus II pertemuan 1 adalah 17,5 dengn kategori sangat aktif dan pada pertemuan 2 adalah 17,7 dengn kategori sangat aktif. Hal ini menunjukkan bahwa indikator keberhasilan untuk aktivitas belajar siswa sudah tercapai.

Pelaksanaan penelitian ini siswa diajak untuk menggunakan alat peraga yaang telah disiapkan, untuk saling memahami dan menghargai perbedaan pendapat, saling melengkapi kekurangan melalui pemberian tanggapan dari temannya dengn cara menyempurnakan hasil jawaban temannya yaang kurang tepat pada saat latihan soal. Pembelajaran yaang melibatkan secara penuh peserta didik, dengn menggunakan alat peraga yaang dapat mengaktifkan siswa sehinngga siswa tidak pasif, jenuh, dan mengurangi ketegangan dalaam berlangsungnya kegiatan belajar mengajar.

Trinandita (1984) menyatakan bahwa "hal yaang paling mendasar yaang dituntut dalaam proses pembelajaran adalah keaktifan siswa “. Keaktifan siswa dalaam proses pembelajaran akan menyebabkan interaksi yaang tinggi anatara guru dengn siswa ataupun siswa itu sendiri. Hal ini mengakibatkan suasana kelas menjadi segar dan kondusif, dimana masing-masing siswa dapat melibatkan kemampuannya seoptimal mungkin. Aktivitas yaang timbul dari siswa akan mengakibatkan terbentuknya pengetahuan dan keterampilan yaang akan mengarah pada peningkatan prestasi.

Dengn melihat hasil yaang telah dicapai dari siklus I ke siklus II menunjukkan bahwa penggunaan alat peraga pada materi pokok himpunan dapat meningkatkan aktivitas dan prestasi belajar siswa. Jadi, penggunaan alat peraga pada materi pokok himpunan dapat meningkatkan aktivitas dan prestasi belajar siswa kelas VIIA SMPN 2 Madapangga tahun pelajaran 2018/2019.

\section{KESIMPULAN}

Berdasarkan analisis data dan pembahasan hasil penelitian, maka dapat disimpulkan bahwa: 1) Penggunaan Alat Peraga dapat meningkatkan aktivitas belajar siswa kelas VIIA SMPN 2 Madapangga pada materi pokok persegi dan pesegi panjang tahun pelajaran 2018/2019. Hal ini dapat dilihat dari hasil observasi, bahwa perolehan skor dan kategori aktivitas mengalami peningkatan dari siklus ke siklus, yaitu siklus I pada pertemuan 1 dengn skor 14,9 (aktif), pada pertemuan 2 dengn skor 17 (sangat aktif), siklus II pada pertemuan 1 dengn skor 17,5 (sangat aktif), pada pertemuan 2 dengn skor 17,7 (sangat aktif); 2) Penggunaan Alat Peraga dapat meningkatkan prestasi belajar siswa kelas VIIA SMPN 2 Madapangga pada materi pokok Himpunan tahun pelajaran 2018/2019. Hal ini dapat dilihat dari persentase ketuntasan yaang diperoleh pada siklus I sebesar 63,64\%, sedangkan pada siklus II sebesar 90,91\%.

Saran-saran yaang dapat disampaikan dengn hasil penelitian ini adalah: 1) Diharapkan kepada siswa untuk mengembangkan kemampuan berfikirnya, melatih mengemukakan pendapat, menambah motivasi belajar, memahami materi lebih mendalaam, sehinngga pada akhirnya dapat meningkatkan aktivitas dan prestasi belajar siswa; 2) Diharapkan kepada guru SMPN 2 Madapangga agar menggunakan 
alat peraga dalaam proses pembelajaran karena dapat meningkatkan aktivitas dan prestasi belajar siswa; dan 3) Diharapkan kepada pihak sekolah agar hasil penelitian ini dapat memberikan sumbangan pemikiran sebagai bentuk inovasi pembelajaran yaang mendukung sistem pembelajaran yaang telah ada.

\section{DAFTAR PUSTAKA}

Arikunto, (2009), Dasar-dasar Evaluasi Pendidikan (Edisi Revisi). Jakarta : Bumi Aksara

Arikunto, Suharsimi, dkk. (2008). Penelitian Tindakan Kelas. Jakarta : PT. Bumi Aksara

Cerah CV. Teguh Karya KTSP Standar Isi (2006). Matematika SMP/MTs Kelas VII

Depdikbud Undang-Undang RI, No 20, (2003). Bab I pasal 1

Djamarah, Prestasi Belajar dan Kompetensi Guru.Surabaya, Usaha Nasional, 2006

Fathurrohman, Pupuh \& M. Sobry Sutikno. (2007). Strategi Belajar Mengajar : Strategi Mewujudkan Pembelajaran Bermakna Melalui Penanaman Konsep Umum dan Konsep Islami. Bandung : PT. Refika Aditama.

Ign. Masidjo, (1995). Penilaian Pencapaian Hasil Belajar Siswa di Sekolah, Yogyakarta, Kanisius.

M.Cholik Adinawan.Sugijono, Penerbit Erlangga.KTSP Standar Isi (2006), Matematika untuk SMP Kelas VII

Nurkencana dan Sumartana, (1990). Evaluasi Pendidikan. Surabaya : Usaha Nasional.

Nuharini, Dewi dan Tri Wahyuni, (2008). Matematika Konsep dan Aplikasinya untuk SMP/ MTs. Kelas VII. Jakarta: Pusat Perbukuan Depaetemen Pendidikan Nasional.

Slameto, (2003). Belajar dan faktor-faktor yaang mempengaruhinya, Jakarta: PT Rineka Cipta.

Sriyanto HJ, (2007). Strategi Sukses Menguasai Matematika (Yogyakarta: Indonesia Cerdas: h. 17-23.

WJS. Poerwadarminta, (1990). Kamus Besar Bahasa Indonesia. Surabaya: Pustaka Setia. 